\title{
Effect of Moringa oleifera Leaf Powder Supplementation on Some Quality Characteristics of Wheat Bread
}

\author{
Abraham I. Sengev ${ }^{1}$, Joseph O. Abu ${ }^{1}$, Dick I. Gernah ${ }^{2 *}$ \\ ${ }^{1}$ Department of Food Science and Technology, University of Agriculture, Makurdi, Nigeria; ${ }^{2}$ Department of Food Science and Tech- \\ nology, University of Mkar, Gboko, Nigeria. \\ Email: *gernah04@yahoo.com
}

Received December $4^{\text {th }}$, 2012; revised January $3^{\text {rd }}$, 2013; accepted January $10^{\text {th }}$, 2013

\begin{abstract}
The effect of Moringa oleifera leaf powder supplementation on some physico-chemical and sensory properties of wheat bread was determined. Bread was prepared from varying proportions of $100 \%, 99 \%, 98 \%, 97 \%$, 96\% and 95\% wheat flour supplemented with $0 \%, 1 \%, 2 \%, 3 \%, 4 \%$ and $5 \%$ Moringa oleifera leaf powder respectively. The bread samples were allowed to cool at ambient temperature $\left(30^{\circ} \mathrm{C} \pm 1^{\circ} \mathrm{C}\right)$ and analysed for some physical properties, proximate composition, and sensory attributes. Moringa leaf powder addition significantly $(\mathrm{p}<0.05)$ increased the fibre $(2.10 \%$ to $3.28 \%)$, ash $(1.10 \%$ to $1.65 \%)$, protein $(9.07 \%$ to $13.97 \%)$, and ether extract (1.51\% to $2.59 \%)$, while decreasing moisture content (35.20\% to $27.65 \%)$. Moringa leaf powder supplementation also significantly $(\mathrm{p}<0.05)$ decreased the loaf volume, weight loss, loaf height and specific loaf volume from 796.70 to $496.70 \mathrm{~cm}^{3}, 32.32$ to $25.65 \mathrm{~g}, 7.00$ to $5.83 \mathrm{~cm}$ and 4.70 to $2.65 \mathrm{~cm}^{3} / \mathrm{g}$ respectively, while the loaf weight increased from 169.20 to $185.86 \mathrm{~g}$. There was a significant (p $<0.05$ ) increase in Magnesium (Mg), Calcium (Ca) and Beta-carotene contents from 0.76 to $1.27 \mathrm{mg} / 100 \mathrm{~g}, 3.67$ to 6.07 $\mathrm{mg} / 100 \mathrm{~g}$ and 0.02 to $3.27 \mathrm{mg} / 100 \mathrm{~g}$ respectively, while Iron $(\mathrm{Fe})$ and Cupper $(\mathrm{Cu})$ contents decreased from 2.74 to 1.25 $\mathrm{mg} / 100 \mathrm{~g}$ and 2.26 to $0.03 \mathrm{mg} / 100 \mathrm{~g}$ respectively. Sensory evaluation showed that although there was significant (p < 0.05) improvement in nutritional composition, the acceptability of all bread samples decreased with increasing level of Moringa supplementation. This implies that despite the high nutrient content of Moringa oleifera powder, it is not a good substitute for wheat in bread production due to its physical characteristics and sensory attributes.
\end{abstract}

Keywords: Bread; Moringa Leaf Powder; $\beta$-Carotene; Physical Properties; Sensory Properties; Supplementation

\section{Introduction}

Bread is an important staple food in Nigeria. It is however, relatively expensive, being made from imported wheat that is not cultivated in the tropics for climatic reasons [1]. Wheat importation represents an immense drain on the economy while also suppressing and displacing indigenous cereals, with a resultant detrimental effect on agricultural and technological development. Consequently, the idea of substituting part of wheat with other starchy crops is not new.

One of the key efforts in this area include the composite flour program which seeks to substitute flours, starches and protein concentrates from indigenous crops such as cassava, maize, yam, sorghum and millet, for as much wheat as possible in baked products. With the increasing consumption of bread and other baked products in many countries, the composite flour programme promises to save significant amount of foreign exchange, provide nutritious food to more people at lower cost and to utilize

${ }^{*}$ Corresponding author. indigenous crops to a greater extent.

Different levels of success have also been recorded with the use of flours from legumes, cereals, roots and tubers in baked goods [2-4]. Although there is now a substantial amount of available composite bread technology, such breads still require at least 70 percent wheat flour to be able to rise [5] and are generally deficient in micronutrients.

The drumstick tree (Moringa oleifera) referred to as the "miracle plant" and known as "Zogale" in Hausa, "Okwe Oyiibo" in Ibo, "Ewe Ile" in Yoruba and "JeghelAgede" in Tiv is common throughout the West African region [6], thus making the seeds easily available. The leaves are outstanding as a source of vitamin A, B group and $C$ (when raw), and are among the best plant sources of minerals. They contain more iron than "kontonmire", seven times the vitamin $\mathrm{C}$ in oranges, four times the calcium in milk, four times the vitamin A in carrots, two times, the protein in milk and three times the potassium in bananas. They are excellent sources of protein, but poor in carbohydrates and fats, thus making them one of 
the best plant foods available in nature [6].

The leaves are beneficial in the treatment of many ailments due to their various medicinal properties and their rich iron content. In Africa, nursing mothers have been shown to produce more milk when Moringa leaves were added to their diets. Severely malnourished children have been shown to make significant weight gains when care givers add Moringa leaves to their diet [6]. Supplementation of wheat with Moringa oleifera powder could therefore significantly improve the nutritional quality of the composite flours, especially in micro-nutrients.

This study was therefore carried out to assess the possibility of producing acceptable bread with enhanced nutritional value by supplementation of wheat flour with Moringa oleifera leaf powder.

\section{Materials and Methods}

\subsection{Sample Procurement/Preparation}

Wheat flour and all ingredients for baking (sugar, fat, salt, yeast,) used for this work were purchased from Wurukum Market, while matured Moringa oleifera leaves were obtained from Ashar Ijir hamlet, opposite Special Science School, along University of Agriculture Road, North Bank, Makurdi, Benue State. Destalking, washing, drying and grinding of the leaves were all carried out using the method described by Gernah and Sengev [7]. Five blends of wheat flour (WF) and Moringa leaf powder (MLP) were then formulated in the following ratios, 99:1, 98:2, 97:3, 96:4 and 95:5 from which doughs were prepared for production of the bread samples, with $100 \%$ WF as control.

\subsection{Baking}

Doughs from the flour blends were baked using the straight-dough method Chauhan et al. [8] with some modification. The baking formula was $500 \mathrm{~g}$ of flour blend, $9 \mathrm{~g}$ of compressed baker's yeast, $5 \mathrm{~g}$ of salt $(\mathrm{NaCl})$, $13 \mathrm{~g}$ of cane sugar, $10 \mathrm{~g}$ of vegetable shortening and approximately $280 \mathrm{ml}$ of water. All the ingredients were mixed in a Kenwood mixer (Model A $907 \mathrm{D}$ ) for $3.5 \mathrm{~min}$. The doughs were fermented for $90 \mathrm{~min}$ at $28^{\circ} \mathrm{C} \pm 1^{\circ} \mathrm{C}$ then punched, scaled to $250 \mathrm{~g}$ dough pieces, proofed for $90 \mathrm{~min}$ at $30^{\circ} \mathrm{C}, 85 \%$ relative humility and baked at $250^{\circ} \mathrm{C}$ for $30 \mathrm{~m}$

\subsection{Analyses}

\subsubsection{Chemical Properties}

Moisture, crude protein, crude fat, crude fibre and ash were determined according to standard methods described by AOAC [9], while carbohydrate was determined by difference as described by Ihekoronye and Ngoddy [10]. Mineral composition was determined using the Atomic
Absorption Spectrophotometer (AAS) (UNICAM 960 series) as described by AOAC [9], while $\beta$-Carotene was determined by the method of Akpapunam and Ibiama [11].

\subsubsection{Physical Properties}

Loaf volume was determined by the sorghum displacement method [12]; loaf weight by the method of AACC [13], specific loaf volume as described by Penfield and Campbell [14], while loaf height was measured using a meter rule. The dough and the baked loaves were weighed and percent weight loss calculated.

\subsubsection{Sensory Evaluation}

Sensory evaluation was performed 24 hours after baking to evaluate crust colour, crumb colour, crumb texture, flavour and overall acceptability of the bread samples as described by Meilgaard [15].

\subsubsection{Statistical Analyses}

Data were generated in triplicate and subjected to analysis of variance. Means were tested for significant differences by Duncan's Multiple Range Test (DMRT) [16]. Significance was accepted at $\mathrm{p}<0.05$.

\section{Results and Discussion}

\subsection{Effect of Moringa Leaf Powder on the Proximate Composition of Bread}

The chemical properties of wheat flour and Moringa oleifera leaf powder are shown in Table 1, while the proximate composition of bread samples is shown in Table 2. The moisture content decreased significantly (p $<0.05$.) from $35.20 \%$ in $100 \%$ WF to $27.65 \%$ in $95 \mathrm{WF}$ : 5 MLP composite bread. This could be due to the low moisture content of Moringa leaf powder used in the blends and might have implications in terms of the texture and microbiological quality of bread processed with added Moringa leaf powder. Olaoye et al. [1] reported similar values for wheat, plantain and soybean composite bread. The moisture content of foods is usually used as an indicator of food quality. It is important to measure the moisture content in breads because of its potential impact on the sensory, physical, and microbial properties of the bread.

Conversely there was significant $(\mathrm{p}<0.05)$ increase in protein content with increasing level of supplementation from $9.07 \%$ in $100 \%$ WF to $13.79 \%$ in 95 WF:5 MLP blend. This could be due to substitution effect caused by the high protein content of Moringa leaf powder (Table 1). Gernah and Chinma [4] also reported this effect when wheat bread was produced with maize/ soyabean blends.

The ether extract, crude fibre and ash contents increased significantly $(\mathrm{p}<0.05$ ) from $1.51 \%$ to $2.65 \%$, 
Table 1. Chemical Properties of Wheat Flour and Moringa oleifera Leaf Powder.

\begin{tabular}{ccc}
\hline Parameter & Wheat Flour & Moring $\boldsymbol{a}$ Leaf Powder \\
\hline Moisture (\%) & $12.50 \pm 0.02$ & $6.46 \pm 0.01$ \\
Crude protein (\%) & $11.20 \pm 0.04$ & $27.82 \pm 0.06$ \\
Ether Extract (\%) & $1.43 \pm 0.02$ & $3.10 \pm 0.01$ \\
Crude Fibre (\%) & $2.50 \pm 0.01$ & $19.32 \pm 0.03$ \\
Ash (\%) & $1.67 \pm 0.01$ & $5.36 \pm 0.01$ \\
Carbohydrate (\%) & $69.70 \pm 0.04$ & $38.20 \pm 0.02$ \\
$\beta$-Carotene(mg/100g) & $0.01 \pm 0.01$ & $5.23 \pm 0.03$ \\
Iron (mg/100g) & $3.05 \pm 0.02$ & $8.30 \pm 0.01$ \\
Magnesium (mg/100g) & $141.00 \pm 0.04$ & $244.00 \pm 0.02$ \\
Calcium (mg/100g) & $27.60 \pm 0.02$ & $442.20 \pm 0.03$ \\
Potassium (mg/100g) & $312.00 \pm 0.01$ & $1320.00 \pm 0.01$ \\
Copper (mg/100g) & $2.66 \pm 0.02$ & $3.10 \pm 0.04$ \\
\hline
\end{tabular}

Table 2. Proximate composition of bread supplemented with Moringa oleifera leaf powder.

\begin{tabular}{ccccccc}
\hline Blend & Moisture & Crude Protein & Ether extract & Ash & Crude Fibre & Carbohydrate \\
\hline 100 WF & $35.20 \pm 0.63^{\mathrm{a}}$ & $9.07 \pm 0.61^{\mathrm{a}}$ & $1.51 \pm 0.01^{\mathrm{a}}$ & $1.10 \pm 0.01^{\mathrm{a}}$ & $2.10 \pm 0.05^{\mathrm{a}}$ & $51.02 \pm 1.21^{\mathrm{a}}$ \\
99 WF:1 MLP & $32.21 \pm 0.28^{\mathrm{b}}$ & $10.17 \pm 0.30^{\mathrm{b}}$ & $1.79 \pm 0.04^{\mathrm{b}}$ & $1.18 \pm 0.03^{\mathrm{b}}$ & $2.23 \pm 0.07^{\mathrm{b}}$ & $52.42 \pm 1.17^{\mathrm{a}}$ \\
98 WF:2 MLP & $30.51 \pm 0.07^{\mathrm{c}}$ & $11.22 \pm 0.02^{\mathrm{c}}$ & $1.90 \pm 0.05^{\mathrm{c}}$ & $1.28 \pm 0.03^{\mathrm{c}}$ & $2.46 \pm 0.02^{\mathrm{c}}$ & $52.63 \pm 0.09^{\mathrm{a}}$ \\
97 WF:3 MLP & $28.72 \pm 0.29^{\mathrm{d}}$ & $12.36 \pm 0.14^{\mathrm{d}}$ & $1.99 \pm 0.03^{\mathrm{d}}$ & $1.40 \pm 0.05^{\mathrm{d}}$ & $2.71 \pm 0.12^{\mathrm{d}}$ & $52.82 \pm 0.80^{\mathrm{a}}$ \\
96 WF:4 MLP & $29.01 \pm 0.36^{\mathrm{e}}$ & $12.96 \pm 0.17^{\mathrm{e}}$ & $2.15 \pm 0.01^{\mathrm{e}}$ & $1.61 \pm 0.03^{\mathrm{e}}$ & $3.21 \pm 0.01^{\mathrm{e}}$ & $51.06 \pm 0.35^{\mathrm{a}}$ \\
95 WF:5 MLP & $27.65 \pm 0.01^{\mathrm{f}}$ & $13.97 \pm 0.01^{\mathrm{f}}$ & $2.65 \pm 0.03^{\mathrm{f}}$ & $1.65 \pm 0.05^{\mathrm{e}}$ & $3.28 \pm 0.03^{\mathrm{e}}$ & $50.08 \pm 0.06^{\mathrm{a}}$ \\
LSD & 0.60 & 0.51 & 0.06 & 0.06 & 0.11 & 1.38 \\
\hline
\end{tabular}

Values are mean \pm standard deviation of triplicate determinations. Means in the same column not followed by the same superscript letters are significantly (p $<$ 0.05) different. Key: WF $=$ Wheat Flour; MLP $=$ Moringa Leaf Powder; LSD = Least Significant Difference.

$2.10 \%$ to $3.28 \%$ and $1.10 \%$ to $1.65 \%$ respectively. This could be due to the higher fat, crude fibre and ash contents of Moringa leaf powder as shown in Table 1.

There was no significant difference $(\mathrm{p}>0.05)$ in carbohydrate content, which ranged from $51.02 \%$ to $52.82 \%$ as the percentage of Moringa leaf powder supplementation increased. The slight differences observed could be due to dilution effect during supplementation with Moringa leaf powder which had a carbohydrate content of $38.20 \%$ as against 69 20\% (Table1).

\subsection{Effect of Moringa Leaf Powder on the Physical Properties of the Bread Samples}

Table 3 shows the physical properties of bread produced from composite flours of wheat and Moringa leaf powder. Loaf volume and specific volume decreased significantly $(\mathrm{p}<0.05)$ from 796.70 to $495.73 \mathrm{~cm}^{3}$ and 4.70 to 2.65 $\mathrm{cm}^{3} / \mathrm{g}$ respectively. This could be due to the reduction in gluten content as a result of supplementation. It has also been reported by other researchers that partial replacement of wheat flour with non-glutinous flour results in lower bread volumes $[4,8,12]$. Increase in yeast dosage and longer fermentation/proofing time could possibly help improve these physical characteristics.

Loaf volume is regarded as the most important bread characteristic since it provides a quantitative measurement of baking performance [17]. Loaf volume is also extremely important to consumers because they desire breads that appear to be light and not so dense. The significant decrease in height from 7.00 to $5.83 \mathrm{~cm}$ of the bread could again be attributed to the reduction in gluten content of the blends.

Loaf weight and weight loss are inversely related. While loaf weight increased significantly $(p<0.05)$ as the percentage of Moringa leaf flour increased, weight loss decreased. Both effects could be attributed to inadequate fermentation during bread making process as the percentage of Moringa leaf powder increased. Keetels et al. [18] reported that weight loss is a natural occurrence in the bread making process. Usually, carbon dioxide $\left(\mathrm{CO}_{2}\right)$ is trapped in small air pockets as the dough ferments. During baking, the trapped $\mathrm{CO}_{2}$ causes the air pockets to expand, and later the starch gelatinizes, transforming the dough into an elastic bread crumb. During this transformation, bread loses weight.

For communities that prefer low volume/high weight bread, these bread samples will be acceptable in terms of 
their physical characteristics.

\subsection{Effect of Moringa Leaf Powder on the Mineral and $\beta$-Carotene Contents of the Bread Samples}

The mineral and $\beta$-carotene contents of bread supplemented with Moringa leaf powder are presented in Table 4. The mineral content of the bread samples increased significantly $(\mathrm{p}<0.05)$ as the levels of supplementation increased. This could be ascribed to substitution effect caused by the high levels of Iron (Fe) and Copper $(\mathrm{Cu})$, Magnesium (Mg) and Calcium (Ca) contents in Moringa leaf of $8.30,3.10,244.00$ and $442.20 \mathrm{mg} / 100 \mathrm{~g}$ respectively (Table 1). Gernah and Sengev [7] also reported iron content of $26.20 \mathrm{mg} / 100 \mathrm{~g}$; while Barminas et al. [19] reported $454.00 \mathrm{mg} / 100 \mathrm{~g}$ calcium and $450.60 \mathrm{mg} / 100 \mathrm{~g}$ magnesium in Moringa leaf powder.

Beta-carotene content increased significantly $(\mathrm{p}<0.05)$ from 0.02 to $0.97 \mathrm{mg} / 100 \mathrm{~g}$, with increase in Moringa leaf powder. This could be due to the much higher level of $\beta$-carotene in Moringa leaf powder (5.23 mg/100g) as compared to wheat flour $(0.01 \mathrm{mg} / 100 \mathrm{~g})$ (Table 1). Gernah and Sengev [7] also reported a high value of 5232.40 $\mathrm{mg} / 100 \mathrm{~g}$ total carotenoids for Moringa leaf powder.

\subsection{Effect of Moringa Leaf Powder on the Sensory Attributes of the Bread Samples}

The general appearance of the bread samples is as shown in Plates 1 and 2, while the mean scores of the sensory attributes are presented in Figure 1. There was significant $(\mathrm{p}<0.05)$ decrease in preference in all the attributes evaluated as the percentage of Moringa leaf powder

Table 3. Physical Properties of Bread Supplemented with Moringa oleifera Leaf Powder.

\begin{tabular}{|c|c|c|c|c|c|}
\hline Blend (\%) & Loaf Volume $\left(\mathrm{cm}^{3}\right)$ & Loaf weight (g) & Loss Weight (g) & Loaf Height (cm) & Specific Volume $\left(\mathrm{cm}^{3} / \mathrm{g}\right)$ \\
\hline $100 \mathrm{WF}$ & $796.70 \pm 5.80^{\mathrm{a}}$ & $169.20 \pm 1.48^{\mathrm{a}}$ & $32.32 \pm 0.60^{\mathrm{a}}$ & $7.00 \pm 0.50^{\mathrm{a}}$ & $4.70 \pm 0.03^{\mathrm{a}}$ \\
\hline 99 WF:1 MLP & $698.30 \pm 2.90^{\mathrm{b}}$ & $177.00 \pm 1.06^{\mathrm{b}}$ & $29.20 \pm 0.43^{\mathrm{b}}$ & $6.73 \pm 0.25^{b}$ & $3.91 \pm 0.04^{\mathrm{b}}$ \\
\hline 98 WF:2 MLP & $690.00 \pm 5.00^{\mathrm{b}}$ & $178.05 \pm 1.10^{\mathrm{b}}$ & $28.81 \pm 0.47^{\mathrm{b}}$ & $6.26 \pm 0.25^{b}$ & $3.95 \pm 0.19^{b}$ \\
\hline 97 WF:3 MLP & $603.30 \pm 5.70^{c}$ & $177.52 \pm 1.38^{\mathrm{b}}$ & $28.99 \pm 0.55^{b}$ & $4.60 \pm 0.36^{\mathrm{c}}$ & $3.39 \pm 0.04^{\mathrm{c}}$ \\
\hline 96 WF:4 MLP & $553.30 \pm 5.20^{\mathrm{d}}$ & $184.51 \pm 1.67^{\mathrm{c}}$ & $26.19 \pm 0.67^{\mathrm{c}}$ & $5.33 \pm 0.15^{\mathrm{d}}$ & $2.99 \pm 0.04^{\mathrm{d}}$ \\
\hline $95 \mathrm{WF}: 5$ MLP & $496.70 \pm 5.50^{\mathrm{e}}$ & $185.86 \pm 2.49^{c}$ & $25.65 \pm 1.00^{c}$ & $5.83 \pm 0.28^{\mathrm{db}}$ & $2.65 \pm 0.09^{\mathrm{e}}$ \\
\hline LSD & 11.29 & 2.85 & 0.56 & 0.16 & 1.14 \\
\hline
\end{tabular}

Values are mean \pm standard deviation of triplicate determinations.Means in the same column not followed by the same superscript letters are significantly (p $<$ 0.05) different. Key: WF = Wheat Flour; MLP = Moring $a$ Leaf Powder; LSD = Least Significant Difference.

Table 4. Mineral and $\beta$-carotene Contents of Bread Supplemented with Moringa oleifera Leaf Powder (mg/100g).

\begin{tabular}{cccccc}
\hline Blend & Fe & Mg & Ca & Cu & Beta carotene \\
\hline 100 WF & $2.74 \pm 0.08^{\mathrm{a}}$ & $0.76 \pm 0.01^{\mathrm{d}}$ & $3.67 \pm 0.01^{\mathrm{f}}$ & $2.26 \pm 0.01^{\mathrm{a}}$ & $0.02 \pm 0.01^{\mathrm{e}}$ \\
$99 \mathrm{WF}: 1 \mathrm{MLP}$ & $2.76 \pm 0.09^{\mathrm{a}}$ & $1.06 \pm 0.02^{\mathrm{c}}$ & $5.18 \pm 0.02^{\mathrm{e}}$ & $2.27 \pm 0.03^{\mathrm{b}}$ & $0.35 \pm 0.01^{\mathrm{d}}$ \\
$98 \mathrm{WF}: 2 \mathrm{MLP}$ & $2.79 \pm 0.02^{\mathrm{a}}$ & $1.08 \pm 0.00^{\mathrm{c}}$ & $7.32 \pm 0.02^{\mathrm{a}}$ & $2.27 \pm 0.01^{\mathrm{b}}$ & $0.41 \pm 0.00^{\mathrm{c}}$ \\
$97 \mathrm{WF}: 3 \mathrm{MLP}$ & $2.82 \pm 0.03^{\mathrm{a}}$ & $1.21 \pm 0.02^{\mathrm{b}}$ & $6.72 \pm 0.01^{\mathrm{b}}$ & $2.28 \pm 0.00^{\mathrm{c}}$ & $0.67 \pm 0.01^{\mathrm{b}}$ \\
$96 \mathrm{WF}: 4 \mathrm{MLP}$ & $2.84 \pm 0.01^{\mathrm{b}}$ & $1.24 \pm 0.04^{\mathrm{b}}$ & $5.62 \pm 0.40^{\mathrm{d}}$ & $2.30 \pm 0.02^{\mathrm{d}}$ & $0.76 \pm 0.02^{\mathrm{b}}$ \\
$95 \mathrm{WF}: 5 \mathrm{MLP}$ & $2.87 \pm 0.01^{\mathrm{b}}$ & $1.27 \pm 0.01^{\mathrm{a}}$ & $6.07 \pm 0.08^{\mathrm{c}}$ & $2.31 \pm 0.01^{\mathrm{e}}$ & $0.97 \pm 0.01^{\mathrm{a}}$ \\
LSD & 0.09 & 0.03 & 0.07 & 0.01 & 0.02 \\
\hline
\end{tabular}

Values are mean \pm standard deviation of triplicate determinations. Means in the same column not followed by the same superscript letters are significantly (p $<$ 0.05) different. Key: WF = Wheat Flour; MLP = Moringa Leaf Powder; LSD = Least Significant Difference.

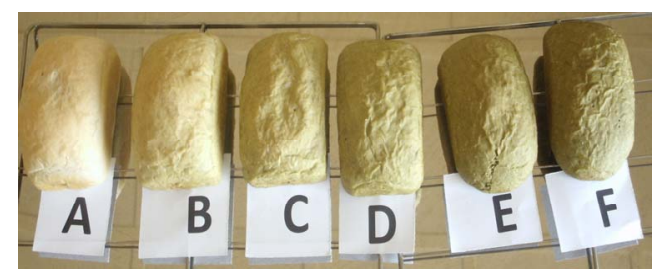

$\mathrm{A}=100 \% \mathrm{WF} ; \mathrm{B}=99 \% \mathrm{WF}: 1 \% \mathrm{MLP} ; \mathrm{C}=98 \% \mathrm{WF}: 2 \% \mathrm{MLP} ; \mathrm{D}=97 \%$ WF:3\% MLP; $\mathrm{E}=96 \% \mathrm{WF}: 4 \%$ MLP; $\mathrm{F}=95 \% \mathrm{WF}: 5 \%$ MLP; WF = Wheat Four; MLP = Moringa Leaf Powder.

Plate 1. Crust appearance of bread supplemented with Moringa leaf powder.

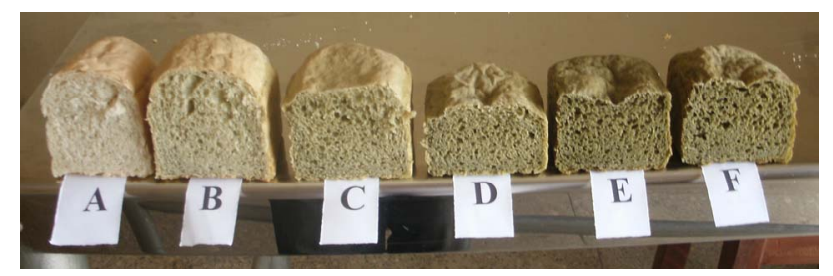

$\mathrm{A}=100 \% \mathrm{WF} ; \mathrm{B}=99 \% \mathrm{WF}: 1 \% \mathrm{MLP} ; \mathrm{C}=98 \% \mathrm{WF}: 2 \% \mathrm{MLP} ; \mathrm{D}=97 \%$ WF:3\% MLP; E = 96\% WF:4\% MLP; F = 95\% WF:5\% MLP; WF = Wheat Four; MLP = Moringa Leaf Powder.

Plate 2. Crumb appearance of bread supplemented with Moringa leaf powder. 


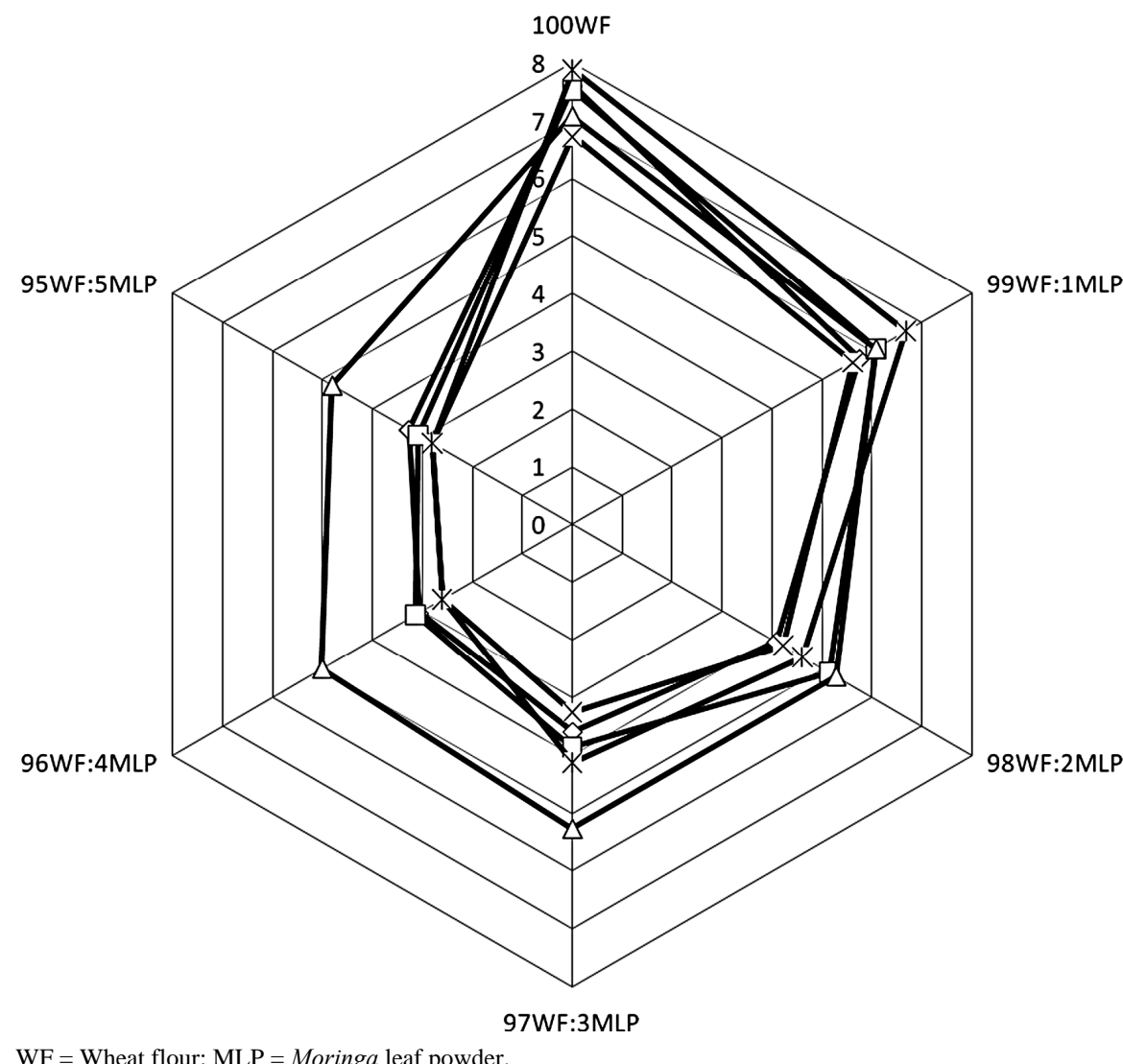

Figure 1. Sensory attributes of bread supplemented with Moringa leaf powder.

increased. The significant $(\mathrm{p}<0.05)$ decrease in likeness for crust and crumb as the level of supplementation increased could be ascribed to the green colour of the bread imparted by the chlorophyll content of the leaves which was also alien to consumers. The decrease in likeness for flavour of the bread samples could be attributed to the herbal flavour of the leaf powder. The decrease in general acceptability with increase in the percentages of Moringa leaf powder implies that panelists did not accept bread supplemented with Moringa leaf powder.

The use of flavouring agents to mask the unacceptable herbal flavor of Moringa oleifera powder could help improve the acceptability of these products.

\section{Conclusion}

Bread was successfully produced from composite flours of wheat flour and Moringa leaf powder. Though the bread samples all had increased nutrients (fibre, protein, fat, minerals and $\beta$-carotene), they had poor physical characteristics (loaf volume, specific volume, loaf height and loaf weight) which became more pronounced with increase in Moringa leaf powder addition. Increase in
Moringa leaf powder substitution drastically reduced the preference/acceptability of the bread samples.

\section{REFERENCES}

[1] O. A. Olaoye, A. A. Onilude and O. A. Idowu, "Quality Characteristics of Bread Produced from Composite Flours of Wheat, Plantain and Soybeans," African Journal of Biotechnology, Vol. 5, No. 11, 2006, pp. 1102-1106.

[2] S. Dhingra and S. Jood, "Physico-Chemical and Nutritional Properties of Cereal-Pulse Blends for Bread Making,” Nutrition and Health, Vol. 16, No. 3, 2002, pp. 183-194. doi:10.1177/026010600201600304

[3] A. Basman and H. Koksel, "Utilization of Transgluranase to Increase the Level of Barley and Soy Flour Incorporation in Wheat Flour Breads," Journal of Food Science, Vol. 68, No. 8, 2003, pp. 2453-2460. doi:10.1111/j.1365-2621.2003.tb07045.x

[4] D. I. Gernah and C. E. Chinma, "Bread-Making Potentials of Cassava, Maize and Soyabean Flour Blends," Journal of Sustainable Agriculture and the Environment, Vol. 8, No. 2, 2006, pp. 196-206.

[5] G. Eggleston, P. F. Omoaka and D. O. Thechioha, "Development and Evaluation of Products from Cassava 
Flour as New Alternatives to Wheaten Breads,” Journal of the Science of Food and Agriculture, Vol. 56, No. 3, 1992, pp. 377-385. doi:10.1002/jsfa.2740590315

[6] L. L. Price, “The Moringa Tree,” 2000. http://www.echonet.org

[7] D. I. Gernah and A. I. Sengev, "Effect of Processing on Some Chemical Properties of the Drumstick Tree (Moringa oleifera) Leaves,” Nigerian Food Journal, Vol. 29, No. 1, 2011, pp. 70-77.

[8] G. S. Chauhan, R. R. Zillman and N. A. M. Eskin, "Dough Mixing and Bread Making Properties of Quinoa-Wheat Flour Blends,” International Journal of Food Science \& Technology, Vol. 27, No. 6, 1992, pp. 701-705. doi:10.1111/j.1365-2621.1992.tb01241.x

[9] Association of Official Analytical Chemists (AOAC), “Official Methods of Analysis," 17th Edition, Association of Official Analytical Chemists, Arlington, 2005.

[10] A. I. Ihekoronye and P. O. Ngoddy, "Integrated Food Science and Technology for the Tropics," Macmillan Publisher LTD, London, 1985.

[11] M. A. Akpapunam and E. A. Ibiama, "Manual of Food Chemistry," Rivers State University of Science and Technology, Port Harcourt, 1985.

[12] J. L. Greene and A. C. Bovell-Benjamin, "Macroscopic and Sensory Evaluation of Bread Supplemented with Sweet Potato Flour,” Journal of Food Science, Vol. 69,
No. 4, 2004, pp. 167-173.

[13] American Association of Cereal Chemists (AACC), “Approved Methods of American Association of Cereal Chemists," 10th Edition, American Association of Cereal Chemists, Inc., St. Paul, 2000.

[14] M. P. Penfield and A. M. Campbell, "Experimental Food Science,” 3rd Edition, Academic Press, San Diego, 1990.

[15] M. C. Meilgaard, G. V. Civille and B. T. Carr, "Sensory Evaluation Techniques,” 4th Edition, CRC Press L.L.C., New York, 2007.

[16] T. A. T. Wahua, "Applied Statistics for Scientific Studies,” African Link Books Ltd., Ibadan, 1999.

[17] K. M. Tronsmo, E. M. Faergestad, J. D. Schofield and S. Magnus, "Wheat Protein Quality in Relation to Baking Performance Evaluated by the Chorleywood Bread Process and a Hearth Bread Baking Test," Journal of Cereal Science, Vol. 38, No. 2, 2003, pp. 205-215. doi:10.1016/S0733-5210(03)00027-4

[18] C. J. A. M. Keetels, K. A. Visser, T. van Vliet, A. Jurgens and P. Walstra, "Structure and Mechanics of Starch Bread,” Journal of Cereal Science, Vol. 24, No. 1, 1996, pp. 15-26. doi:10.1006/jcrs.1996.0033

[19] J. T. Barminas, M. Charles and D. Emmanuel, "Mineral Composition of Non-Conventional Leafy Vegetables," Plant Foods for Human Nutrition, Vol. 53, No. 1, 1998, pp. 29-36. doi:10.1023/A:1008084007189 